\title{
A LEI ANTIMONOPÓLIO DA CHINA E O SEU REGIME DE CONTROLE DE CONCENTRAÇÃO
}

Wei Dan

CHINA'S ANTI-MONOPOLY LAW AND ITS MERGER CONTROL REGIME

\section{RESUMO}

COMO A MAIOR ECONOMIA EMERGENTE E UMA GRANDE POTÊNCIA ECONÓMICA DO MUNDO, A CHINA É UM TARDIO, MAS UM IMPORTANTE PARTICIPANTE DO CLUBE DO DIREITO DA CONCORRÊNCIA, COM A ENTRADA EM VIGOR DE UMA NOVA LEI Antimonopólio (LAM), em $1{ }^{\circ}$ DE Agosto de 2008. O PRESENTE TRABALHO FOCALIZA O REGIME DE CONTROLE DAS OPERAÇÕES DE CONCENTRACC̃̃O ATRAVÉS DA AVERIGUACC̃̃ DE UMA SÉRIE DE REGULAMENTOS DE EXECUÇÃO PROMULGADOS DEPOIS DA LAM. A LUZ DAS NORMAS SUBSTANTIVAS E PROCESSUAIS DO REGIME DO CONTROLE DE CONCENTRAÇÃO, O ESTUDO FAZ UMA COMPARACCÃO ENTRE O REGIME CHINÊS E OS REGIMES dOS Estados ÚNIDOS E DA UNIÃO EUROPEIA. ALGUNS RESULTADOS EMPÍRICOS ILUSTRAM QUE A CHINA ESTÁ FAZENDO ESFORÇOS PARA REALIZAR UMA CONVERGÊNCIA SUAVE COM AS NORMAS INTERNACIONAIS, ENQUANTO A ABORDAGEM GRADUAL DE CONVERGÊNCIA DÁ À CHINA A FLEXIBILIDADE PARA PARAR, AJUSTAR E FAZER UMA EXCEPÇÃO SEMPRE QUE NECESSÁRIO

\section{PALAVRAS-CHAVE}

Lei Antimonópolio; Antitrust; China; Controle de CONCENTRAÇÃO; DIREITO COMPARADO.

\author{
ABSTRACT \\ AS THE BIGGEST EMERGING ECONOMY AND A MAJOR ECONOMIC \\ POWER IN THE WORLD, CHINA IS A LATE BUT A SIGNIFICANT \\ ENTRANT INTO THE COMPETITION LAW CLUB, WITH THE \\ IMPLEMENTATION OF A NEW ANTI-MONOPOLY LAW (AML) ON \\ 1St AUgust, 2008. THE ARTICLE FOCUSES ON THE MERGER \\ ENFORCEMENT BY EXAMINING THE IMPLEMENTING \\ REGULATIONS AND ORDERS RELATED TO MERGER CONTROL \\ WHICH WERE ISSUED AFTER THE ENACTMENT OF THE AML. IN \\ LIGHT OF THE SUBSTANTIVE STANDARDS AND THE \\ PROCEDURAL REQUIREMENTS OF MERGER CONTROL, THE \\ ARTICLE MAKES A COMPARISON BETWEEN CHINESE REGIME \\ AND THE U.S. AND EU'S STANDARDS. SOME EMPIRICAL \\ FINDINGS ON THE AML AND ITS MERGER ENFORCEMENT HAS \\ LARGELY ILLUSTRATED THAT CHINA IS MAKING ITS EFFORTS TO \\ REALIZE A SOFT CONVERGENCE WITH INTERNATIONAL NORMS, \\ MEANWHILE, THE GRADUAL APPROACH OF CONVERGENCE \\ GIVES CHINA THE FLEXIBILITY TO STOP, TO ADJUST AND TO \\ MAKE AN EXCEPTION WHENEVER NECESSARY.

\section{KEYWORDS} \\ ANTI-MONOPOLY LAW; ANTITRUST; CHINA; MERGER \\ CONTROL; COMPARATIVE LAW.
}

\section{i Visão geral da Lei Antimonopólio da China}

\section{I ANTeCedentes}

Nos últimos trinta anos, uma das mudanças mais notáveis do Direito e pensamento jurídico em todos os países em desenvolvimento tem-se reflectido na legislação do Direito da Concorrência. Em 1980, apenas quinze países tinham leis da concorrência 
ou antitrust, mas até o final de 2010, mais de 112 países tinham adoptado leis da concorrência e pelo menos catorze países estão em processo de preparação de leis da concorrência. ${ }^{1}$ Por vários anos, muitos dos países em desenvolvimento estavam convencidos de que não havia necessidade de adoptar uma lei da concorrência, porque a intervenção do Estado para regular as actividades económicas era suficientemente forte e os governos poderiam intervir directamente nas práticas comerciais restritivas. Todavia, nos últimos anos, na sequência dos ajustes estruturais das economias domésticas, privatização e desregulamentação, muitos países em desenvolvimento estão conscientes de que as economias de mercado e as reformas económicas domésticas exigem uma boa ordem sustentada pela concorrência leal. Por outro lado, no mercado global, as concentrações e aquisições desencadeadas pela globalização económica e liberalização do comércio e do investimento podem, eventualmente, prejudicar a concorrência leal; os cartéis internacionais podem prejudicar os interesses dos consumidores e os acordos verticais de monopólio podem excluir da concorrência os operadores económicos estrangeiros. Tendo em conta que todos tipos de condutas monopolistas nos mercados internacionais irão afectar, directa ou indirectamente, os interesses nacionais vitais, hoje em dia, os legisladores e formuladores de políticas de muitos países em desenvolvimento não duvidam do papel positivo do Direito da Concorrência e da política da concorrência na protecção da alocação racional de recursos, melhorando o bem-estar social da humanidade e promovendo o desenvolvimento económico.

\section{I.2 O DESENVOLVIMENTO LEGISLATIVO DA ChinA E A IMPORTÂNCIA dA PRomulgação da Lei Antimonopólio (LAM)}

Como a maior economia emergente e uma grande potência económica do mundo, a China é um tardio, mas um importante participante do clube do Direito da Concorrência, com a entrada em vigor de uma nova Lei Antimonopólio (LAM), em $1^{\circ}$ de agosto de 2008. A LAM é um marco no caminho da transição económica da China, bem como uma questão de grande importância para os operadores económicos estrangeiros.

Quando comparada com outros países do BRICS, a promulgação da LAM da China foi tardia. O Brasil introduziu um regime antitrust em 1962 e incorporou o regime da concentração através da Lei 8884/94, que foi promulgada em 1994 e alterada em 2002. A Rússia adoptou a Lei da Concorrência em 1991 e aprovou a Lei de Defesa da Concorrência em 2006. A primeira Lei da concorrência da Índia foi promulgada em 1969; esta Lei foi substituída pela Lei da Concorrência de 2002, n. 12 de 2003, alterada pela Lei da Concorrência em 2007. A África do Sul promulgou a Lei da Concorrência em 1955 e alterou em 1979, 1988, 2000 e 2009.

A elaboração da LAM foi intensamente debatida e durou quase duas décadas. Talvez, até a data, a LAM seja uma das leis mais controversas e também a única que 
tenha levado o tempo máximo para ser aprovada na China. Como se sabe, as condições básicas para um país elaborar uma Lei da Concorrência dependem do apoio dos políticos nacionais, do conhecimento do Direito estrangeiro, da pressão das instituições estrangeiras, da análise teórica do monopólio nas perspectivas da Economia, Sociologia e Direito, da ética social, e das políticas públicas oportunas, e a China não é uma excepção. A tão esperada LAM foi finalmente aprovada com base em razões económicas, políticas e culturais.

Do ponto de vista económico, sob o sistema de planeamento económico de 1993, as empresas estatais tiveram um papel importante na economia nacional. Naquela época, os poderes administrativos intervinham em todos os campos da vida económica social e o desenvolvimento económico perdeu completamente a vitalidade. Em 1993, a China reviu a Constituição e estabeleceu, formalmente, uma "economia de mercado socialista”. Como a reforma aprofundou e os factores de mercado cresceram constantemente, o monopólio do preço na economia planificada quebrou e o modelo de propriedade na economia nacional tornou-se mais diversificado. A transformação das empresas estatais em sociedades por acções deu-lhes uma grande palavra a dizer na gestão e outros agentes económicos foram também bem envolvidos na concorrência na economia de mercado para atingir a maximização de interesses. $\mathrm{Na}$ China, introduzir a concorrência e promulgar a Lei da Concorrência é uma parte importante da reforma económica, porque um mercado saudável depende muito do Direito da Concorrência, o que pode incentivar a concorrência ideal e garantir uma operação ordenada do mecanismo de mercado. Na realidade, desde os finais dos anos 1970, quando a China iniciou uma política aberta para o mundo exterior, a economia chinesa sofreu danos a vários níveis causados por diferentes práticas anticoncorrenciais. Todavia, a Lei Anticoncorrência Desleal, adoptada em 1993, não contém quaisquer disposições para proibir acordos de monopólio e abuso de posição dominante no mercado ou controlar a concentração de operadores económicos. Além disso, nem a Lei dos Preços de 1997, nem a Lei de Licitações Públicas de 1999 abordam sistematicamente as condutas monopolistas. No final de 2001, a China aderiu à Organização Mundial do Comércio (OMC) e tornou-se plenamente integrada na economia global. O sistema de comércio livre global precisa de uma forte aposta na concorrência leal por todos os participantes. Como membro da economia mundial, a China tem de abraçar as regras actuais para as economias de mercado e as práticas internacionais. Na última década, a China tem sido munida de todos os requisitos da economia de mercado para decretar a Lei da Concorrência.

Do ponto de vista político a LAM dificilmente pode ser adoptada sem o forte apoio dos tomadores de decisão chineses. Em primeiro lugar, a economia chinesa ainda é uma economia de transição de uma economia planificada para uma economia de mercado; as autoridades chinesas são obrigadas a regular e controlar a economia doméstica e o mercado através de meios legais, mas não de medidas administrativas. 
Quando o papel do governo central chinês se tornar menos intrusivo, as forças do mercado e outros agentes privados gradualmente penetram na economia. As funções do governo estão concentradas nos ajustes da economia, na supervisão do mercado, na administração da sociedade e nos serviços públicos. ${ }^{2}$ Ao mesmo tempo, a China insistiu em aplicar a estratégia do Estado de Direito. Nesse sentido, reduzir a intervenção administrativa e aprovar a Lei da Concorrência tornou-se um requisito necessário para a construção legal. Em segundo lugar, a prosperidade económica não levará automaticamente à justiça social e à estabilidade social. De acordo com o "conceito de desenvolvimento científico", deve-se considerar quer a eficiência económica quer a justiça social. Uma afectação eficiente dos recursos não pode ser conseguida à custa de oportunidades de concorrência leal e interesses dos consumidores. O Direito da Concorrência pode desempenhar um papel activo no aumento da eficiência económica e salvaguarda da justiça social. Em terceiro lugar, os tomadores de decisão chineses esperam cumprir os compromissos da adesão à OMC aprovando a LAM. A entrada na OMC e a participação no sistema multilateral de comércio foram uma decisão estratégica da liderança chinesa. Os reformadores chineses têm usado conscientemente as regras internacionais, os seus compromissos internacionais e obrigações para moldar as políticas internas, acelerar a industrialização e a urbanização, e aprofundar as reformas internas, especialmente para desalojar os monopólios nacionais que restringem o crescimento, pois, a abertura pode introduzir ideias avançadas, tecnologias e concorrência. Nesse sentido, a globalização circunscreve o uso da política industrial nacional em determinadas maneiras. A China procura, precisamente, as forças do mercado global, como acção externa ou reforço auxiliar para acelerar a sua transição socioeconómica. A promulgação da LAM vai, por um lado, contribuir para a aceleração do acesso ao mercado interno e transparência do mercado, e por outro lado, proteger as empresas nacionais contra as influências negativas dos monopólios internacionais. Tomando em consideração que o Direito da concorrência envolve diferentes políticas industriais, acelerar o processo legislativo da LAM ajuda a romper a resistência de certos grupos de interesse nacional e a aliviar as pressões, que visam impedir a reforma económica. Em quarto lugar, as autoridades chinesas prestaram muita atenção à aprovação da LAM porque é benéfica para a imagem da China da abertura política, a atracção de investimentos estrangeiros e a optimização do ambiente de investimento.

Em relação à perspectiva cultural, a elaboração da Lei da Concorrência reside na cultura de concorrência, na consciência da sociedade, na pesquisa de estudiosos teóricos, bem como no conhecimento do legislador e experiências sobre Direito da concorrência estrangeiro. Na realidade, devido à influência da economia planificada, a compreensão e cognição da concorrência na sociedade chinesa ainda são ambíguas ou insuficientes. Não só os operadores económicos, que participam na concorrência, mas também outros actores comerciais e consumidores, não têm uma percepção correcta 
sobre concorrência e concorrência desleal. Além disso, muitos departamentos administrativos não ganharam uma consciência clara sobre concorrência ideal e efectiva aplicação da lei. Desde 2000, os estudiosos chineses têm publicado mais estudos aprofundados sobre as leis de concorrência estrangeiras e experiências disponíveis para a China em língua chinesa. Os funcionários chineses têm convidado funcionários estrangeiros e estudiosos, bem como assessores jurídicos de organizações internacionais, para participar em conferências e discussões na China. Além disso, o legislador e autoridades chineses realizaram muitas viagens de campo para a Europa, Estados Unidos e outros países para trocar seus conhecimentos e experiências sobre o Direito da Concorrência. Em 2005, um projecto da LAM foi distribuído entre os especialistas chineses e estrangeiros em antitrust, para comentários, e esse processo ajudou o legislador chinês a, finalmente, incorporar muitas experiências estrangeiras na lei final. ${ }^{3}$ Todos esses desenvolvimentos foram benéficos na formação da cognição da Lei da Concorrência da China.

Assim, o aparecimento da LAM na China é devido a muitos factores de estímulo, e a adopção da economia de mercado cria uma base sólida, com o apoio político que presta a garantia necessária, e a cultura de concorrência constitui o verdadeiro espírito desta lei.

\section{3 Avaliação Geral da lAM na perspectiva do Direito Comparado}

Antes da LAM ser adoptada na China, as regras relativas à concorrência estavam dispersas em cerca de quarenta leis. ${ }^{4} \mathrm{Na}$ ausência de uma lei da concorrência abrangente e sistemática, o legislador chinês tinha pouca escolha, senão consultar as experiências de leis estrangeiras. ${ }^{5} \mathrm{O}$ problema era como fazer a selecção e numerosos acertos entre modelos diferentes. Os funcionários chineses não copiaram a experiência dos outros; em vez disso, eles fizeram a sua própria adaptação, ajuste e inovação à luz dos contextos económico, político, social e cultural chineses. No processo de recriação, o legislador chinês teve a "total liberdade na escolha da forma e conteúdo da legislação". 6

A LAM afecta os acordos de monopólio, o abuso de posição dominante e a concentração de empresas. Depois de quase duas décadas de elaboração, o legislador chinês organizou sob a experiência de outras jurisdições e introduziu programas de clemência, acordos de liquidação, pré-notificação obrigatória de actos de concentração, efeitos extraterritoriais, e muitas outras instituições. À semelhança de outros países emergentes, quando elaboram a regulamentação da concorrência, a China extraiu lições dos dois regimes jurídicos de concorrência mais proeminentes: os Estados Unidos e a Europa. ${ }^{7}$ Tomando-a de um modo geral, a Lei da Concorrência chinesa é muito semelhante à lei da UE, e ainda podemos encontrar alguns sistemas importantes estabelecidos pelo "pai de muitas leis da concorrência" - a lei de concorrência dos EUA (como a regra per se e a regra da razão) - que também foram transplantadas para a lei chinesa. ${ }^{8}$ 
Em geral, a LAM da China espelha as regras europeias da concorrência, pelas seguintes razões: para começar, os objectivos da lei na UE são mais diversificados. Ao contrário da Lei da Concorrência dos EUA, que se concentra principalmente na eficiência económica, a lei da UE estabelece objectivos plurais, como o aumento da eficiência económica, a redução da intervenção pública, a criação de um mercado único, a promoção da equidade social e o crescimento económico. ${ }^{9} \mathrm{Na}$ visão do nível de desenvolvimento da China e as características de sua economia de transição, com excepção para salvaguardar o mecanismo de mercado e aumentar a eficiência económica, a LAM vai também considerar outros objectivos sociais plurais, como reduzir o abuso do poder administrativo para eliminar ou restringir a concorrência, reduzir o proteccionismo local e promover a equidade e justiça sociais. É de notar que o objectivo de criar um mercado único integrado, instituído pela UE, oferece uma importante referência para o legislador chinês. No enorme mercado interno chinês, um bom ambiente para uma concorrência saudável requer a eliminação de todos tipos de barreiras. A LAM representa exactamente um instrumento legal imperativo para regulamentar as actividades do mercado. De acordo com o artigo $1^{\circ}$ da LAM, "a presente lei é aprovada com a finalidade de (...) proteger a concorrência leal no mercado (...) manter os interesses dos consumidores e os interesses públicos e promover o desenvolvimento são da economia de mercado socialista”. Uma vez definidos os objectivos da lei, todas as instituições e regras (como responsabilidades legais e sanções) serão destinadas a alcançar os objectivos básicos estabelecidos pelo legislador.

Segundo, as políticas económicas liberais e as culturas da concorrência são uma parte da tradição americana, e na história económica americana a propriedade pública raramente foi adoptada. Todavia, na Europa, muitos países tiveram experiências de monopólios estatais que eram bastante similares à situação actual da China. Hoje, na China, os monopólios das empresas estatais ainda são comuns. Portanto, a desregulamentação e as experiências legislativas da UE têm fornecido algumas referências para a reforma chinesa.

Terceiro, a tradição legal também é um dos principais motivos. O sistema jurídico americano pertencente à família do Direito anglo-saxónico (Common Law), em que as fontes legais são, principalmente, a jurisprudência, os objectivos e os espíritos da lei dependem da interpretação dos juízes, e o judiciário tem um papel fundamental na Lei da Concorrência dos EUA. Contudo, os países europeus pertencem à família do Direito romano-germânico (Civil Law), em que as fontes legais são, principalmente, a lei escrita e os objectivos e os espíritos da lei são, em geral, expressos pelo legislador. A China é, também, parte do sistema do Direito romanogermânico. Por um lado, a China está contando muito com o modelo legislativo para transmitir os objectivos da lei; por outro lado, os tribunais chineses dificilmente podem cumprir as obrigações da Lei da Concorrência semelhante à maneira dos tribunais americanos. 
Em quarto lugar, ao contrário do modelo judicial para implementar a Lei da Concorrência nos EUA, a UE tem confiado na autoridade administrativa para aplicar a lei. Sendo curtas as experiências de aplicação e implementação, não é prático para a China optar por um modelo judiciário. Considerando que a magistratura administrativa na China tem desfrutado de autoritarismo e experiência, a China assemelha-se ao sistema de aplicação da Lei da Concorrência da UE.

No entanto, a China é muito diferente da UE em termos do nível de desenvolvimento. Não há lei da concorrência universalmente aplicável, que possa ser directamente aplicada em outros países sem adoptar quaisquer variações. Sendo um país emergente que sofre a transformação da estrutura económica, o legislador chinês tem de considerar o seu ambiente político-económico único e os níveis de sofisticação das instituições, buscando não só as experiências dos países desenvolvidos, mas também as de outros países em desenvolvimento ${ }^{10}$ e organizações internacionais. ${ }^{11}$ Enquanto transplanta inúmeras instituições na nova lei, o legislador chinês também fez algumas adaptações ao seu ambiente económico e político, garantindo que a necessidade de desenvolvimento económico torne-se um tema chave quer no pensamento da política de concorrência, quer na redacção legal.

\section{I.4 Modelo de estrutura para A APlicação}

A LAM tem sido considerada uma "constituição económica" ou "carta magna da liberdade económica” na China. ${ }^{12}$ Mesmo assim, devido ao facto de a LAM ter entrado em vigor apenas em 2008 e muitos regulamentos detalhados e regras com vista a implementar a lei ainda não estarem aprovadas, a LAM foi criticada por Kallay como um "tigre de papel", ${ }^{13}$ porque parecia ter apenas valores simbólicos e vontade política, especialmente no exercício das suas restrições sobre os monopólios administrativos e indústrias de monopólio.

Em relação ao desenho institucional das autoridades da concorrência, existem basicamente três modelos adoptados pela maioria dos ordenamentos jurídicos: o modelo judicial bifurcado, o modelo de agência bifurcado, e o modelo de agência integrado. ${ }^{14}$ A LAM pode ser classificada para o modelo de agência integrado, semelhante ao da UE. ${ }^{15}$ As agências de aplicação na China têm dois níveis: (1) a Comissão Antimonopólio do Conselho de Estado (com poderes quase legislativos, como o estudo e elaboração de políticas da concorrência), organização da investigação e a avaliação da situação global da concorrência e publicação de relatório de avaliação, formulação de directrizes e coordenação da aplicação da lei); (2) a Autoridade de Aplicação Antimonopólio (com poder quase judicial), na qual a Secretaria Antimonopólio do Ministério do Comércio (Mofcom), é responsável pela análise das concentrações; o Departamento de Supervisão de Preços da Comissão de Desenvolvimento Nacional e Reforma (CDNR) é responsável pela fixação de preços e cartéis; e o Departamento de Aplicação Antimonopólio e Anticoncorrência Desleal 
da Administração Estatal de Indústria e Comércio (Saic) é responsável pelo abuso do domínio e acordos de monopólio não relacionados com preços. ${ }^{16}$

No geral, o modelo chinês espelha muito o modelo administrativo da UE, mas, ao mesmo tempo, é também muito semelhante ao dos EUA em termos de sobreposição de competências de aplicação. A tendência na maioria das autoridades da concorrência nas economias emergentes e em transição é de conceder-lhes independência administrativa, tanto quanto possível. Conforme comentado por Emch e Hao, “os órgãos encarregados pela aplicação da LAM têm independência limitada e falta do esprit de corps (...) os conflitos de jurisdições parecem ser inevitáveis". ${ }^{17}$ Até agora, as agências da concorrência na China estão apenas começando o seu trabalho e muitos desafios lhes esperam pela frente.

No entanto, é permitido o direito particular de acção, nos termos da LAM. ${ }^{18}$ Os operadores económicos devem assumir responsabilidades civis por danos causados por condutas monopolistas, e os particulares podem processar as violações da LAM. Porém, até agora, nenhum caso vitorioso foi registrado, devido às dificuldades na colecta de provas por parte dos particulares. ${ }^{19}$

\section{AplichęÃo do CONTROlo das CONCENTRAÇÕES}

\section{I QUADRo LeGAL}

As concentrações e aquisições tornaram-se uma ferramenta importante para alcançar a economia de escala, optimizar as estruturas industriais, e aumentar a competitividade das empresas. Por outro lado, devido à alteração da concentração de forças económicas ou da estrutura do mercado, as concentrações e aquisições podem produzir um efeito sobre a concorrência e reduzir o número de concorrentes. Portanto, o controlo das concentrações pode levantar problemas de concorrência e é sempre abordado nas legislações antitrust.

Entre um total de 57 artigos da LAM, 21 estão preocupados com o controlo das concentrações. Desde que a lei entrou em vigor, o controlo das concentrações tem sido activamente implementado pelas autoridades chinesas da concorrência, enquanto a aplicação de regras de comportamento que regem acordos anticoncorrenciais e abuso de posições dominantes na China tem sido mais lenta a começar.

Após a promulgação da LAM, alguns trechos da legislação complementar foram aprovados para melhorar a aplicação do controlo das concentrações, incluindo um regulamento administrativo aprovado pelo Conselho de Estado e quatro regulamentos formulados e publicados pelo Ministério do Comércio, ${ }^{20}$ nomeadamente, as Disposições do Conselho de Estado sobre os Limiares para a Notificação Prévia das Concentrações de Empresas (3 de agosto de 2008, aprovadas pelo Conselho de Estado); as Disposições sobre Concentrações e Aquisições de Empresas Nacionais 
por Investidores Estrangeiros (22 de junho de 2009, aprovadas pelo Ministério do Comércio); ${ }^{21}$ Medidas para a Declaração da Concentração de Empresas (21 de novembro de 2009, aprovadas pelo Ministério do Comércio); Medidas para o Exame da Concentração de Empresas (24 de novembro de 2009, aprovadas pelo Ministério do Comércio); e as Disposições Provisórias sobre a Alienação de Activos ou Negócios nas Concentrações de Empresas (5 de julho de 2010, aprovada pelo Ministério do Comércio). Além disso, algumas orientações sobre Avaliação de Concentrações, que não têm qualquer carácter vinculativo, têm sido anunciadas, como a Orientação do Comité Antimonopólio do Conselho de Estado para a Definição do Mercado Relevante (24 de maio de 2009); as Opiniões Orientadoras do Departamento Antimonopólio do Ministério do Comércio sobre a Declaração das Concentrações de Empresas (5 de janeiro de 2009); as Opiniões Orientadoras do Departamento Antimonopólio do Ministério do Comércio sobre os Documentos e Materiais da Declaração das Concentrações de Empresas (5 de janeiro de 2009); e as Directrizes do Funcionamento do Departamento Antimonopólio do Ministério do Comércio sobre as Concentrações de Empresas ${ }^{22}$ (11 de março de 2010).

\subsection{DEFINIÇÃo DA LAM}

As disposições legais sobre o controlo das concentrações dos diferentes ordenamentos jurídicos mostram mais semelhanças do que diferenças. Considerando que as concentrações podem ocorrer entre concorrentes reais ou potenciais no mesmo nível da cadeia de produção ou de distribuição (as chamadas concentrações horizontais) ou, alternativamente, em diferentes níveis de produção e distribuição (as chamadas concentrações verticais), ou ainda entre partes envolvidas em mercados e actividades totalmente diferentes (as chamadas concentrações conglomeradas), como ponto de partida da regulação, a definição de concentrações e aquisições fornecidas pelo legislador é sempre muito ampla. A China não é excepção a isso. ${ }^{23}$

A terminologia seleccionada pela LAM é "concentração", que se refere a três tipos: (1) as concentrações dos operadores económicos (através da fusão entre duas ou mais empresas previamente existentes e independentes, ou a criação de joint ventures); ${ }^{24}$ (2) aquisição de acções ou activos de operadores económicos; ou (3) o esforço de uma influência decisiva sobre outros operadores económicos por contrato ou qualquer outro meio. ${ }^{25}$ Pode-se observar que o âmbito das concentrações e aquisições dado pelas Disposições relativas a Concentrações e Aquisições de Empresas Nacionais por Investidores Estrangeiros, na versão 2006, que se refere apenas à "Concentração e Aquisição de Capital” e à "Concertação e Aquisição de Activos", 26 foi estendido pela LAM.

A definição na LAM chama a atenção para o efeito do controlo. De acordo com a Lei das Sociedades Comerciais da China, o sócio controlador refere-se àquele cuja contribuição de capital ocupa 50\% ou mais do capital total de uma sociedade por quotas; 
àquele cujas acções ocupam mais de 50\% do total das acções de capital de uma sociedade por acções; àquele cuja contribuição de capital ou proporção da acções é inferior a $50 \%$, mas goza de um direito de voto de acordo com a sua contribuição de capital ou se a quota que detém é suficientemente grande para impor um grande impacto sobre a resolução da reunião dos sócios ou da assembleia dos sócios. Um controlador real é qualquer um que não seja sócio, mas é capaz de manter o controlo real dos actos da sociedade por meio de relações de investimento, acordos ou quaisquer outros mecanismos. ${ }^{27}$

\subsection{ReQuisitos PROCESSUAIS}

\subsection{LIMIARES DA NOTIFICAÇÃO}

Quando comparado com o "teste do comércio", "tamanho de operações", e "tamanho das partes", todos adoptados nos Estados Unidos, ${ }^{28}$ a China aplica um teste jurisdicional do volume de negócios. ${ }^{29}$ Nos termos das Disposições do Conselho do Estado sobre os Limiares para a Notificação Prévia de Concentrações de Empresas, ${ }^{30}$ a notificação é necessária quando: (1) o volume de negócios em todo o mundo de todos os operadores económicos envolvidos na concentração ultrapassa os 10 biliões de yuans no último ano contabilístico, e o volume de negócios na China de pelo menos dois operadores económicos entre eles ultrapassa 400 milhões de yuans, separadamente, no último ano contabilístico; ou (2) o volume de negócios na China de todos os operadores económicos envolvidos na concentração exceder 2 biliões de yuans no último ano contabilístico, e o volume de negócios na China de pelo menos dois operadores económicos entre eles exceder 400 milhões de yuans, separadamente, no último ano contabilístico. Pode ser constatado que os limiares de notificação na lei chinesa são mais estritos do que os limiares de volume de negócios da UE. ${ }^{31}$

Em qualquer caso, o limiar quantitativo exige um prerrequisito essencial, segundo o qual o volume de negócios de cada um de pelo menos duas partes na concentração na China deve ultrapassar 400 milhões de yuans. Estando satisfeitos os limiares, as transacções entre estrangeiros precisam ser levados ao conhecimento das autoridades chinesas da concorrência, à luz da doutrina do efeito prescrito pela LAM. ${ }^{32}$ Especialmente, os limiares que se aplicam na análise das concentrações na China implicam um forte nexo local com o mercado chinês; em outras palavras, as transacções não serão analisadas a menos que haja um nexo entre os mercados internos chineses e essas transacções. Quando comparada com outros países emergentes, como Rússia e Índia, 33 a adopção do nexo local na análise de concentrações chinesa contribui para a redução de potenciais conflitos entre diferentes jurisdições.

Antes da aprovação da LAM, uma versão anterior das Disposições sobre a Concentrações e Aquisições de Empresas Nacionais por Investidores Estrangeiros estabeleceu, em 2006, que o limiar do volume de negócios de qualquer das partes no mercado chinês era de 1,5 biliões de yuans, o número de partes na concentração era 
de dez, e a quota de mercado de qualquer das partes era de 20\%. ${ }^{34}$ Após a promulgação da LAM, o teste jurisdicional da quota de mercado e o teste do número de partes na concentração foram abolidos. Actualmente, essas disposições considerando os limiares para os investidores estrangeiros foram removidos, e todas concentrações e aquisições são avaliadas com base num critério unificado estabelecido pela LAM.

Embora os limiares da notificação estejam satisfeitos, nenhuma apresentação é necessária para as operações intrapessoais na China. Em outras palavras, entre todos operadores económicos envolvidos na concentração, uma parte possui $50 \%$ ou mais do capital ou activos votantes de todos outros operadores económicos, ou a parte não envolvida na concentração possui $50 \%$ ou mais do capital ou activos votantes de cada operador económico envolvido na concentração. ${ }^{35}$ Ao contrário do teste do número de partes na concentração no passado, a adopção de isenção intrapessoal reflecte a convergência da legislação chinesa com as práticas internacionais.

\subsubsection{NotificaÇ̃̃o PRÉVia obrigatória}

À semelhança dos regimes de controlo obrigatório de concentrações dos Estados Unidos e da UE, ${ }^{36}$ antes da execução de uma operação de concentração, a notificação é obrigatória na China. ${ }^{37}$ Nenhuma concentração é permitida a menos que tenha sido liberada pelas autoridades da concorrência.

Mesmo que qualquer operação de concentração de empresa não atinja os limiares da declaração, as partes podem voluntariamente apresentar uma notificação. Quando o Mofcom considerar que tal aplicação será aceita depois de analisar os documentos e materiais da declaração recebidos, deve realizar o exame de aceitação e tomar decisões em conformidade. Nesses casos, as partes poderão decidir se suspendem a operação de concentração ou não, e assumirão o resultado correspondente. ${ }^{38}$

Por outro lado, são também incentivados inquéritos e discussões informais pelo regime chinês. Antes da declaração oficial, um operador económico de uma concentração pode, por escrito, solicitar a consulta sobre as questões relevantes relativas à notificação ao Mofcom. ${ }^{39}$ De acordo com as Opiniões Orientadoras do Departamento Antimonopólio do Ministério do Comércio sobre a Declaração das Concentrações de Empresas, após receber o pedido por escrito, que deve conter curtos briefings da transaç̧ão e outros documentos e materiais necessários, o Mofcom procederá a uma discussão informal ou negociação com o operador económico, a seu pedido. ${ }^{40} \mathrm{O}$ processo de consulta poderia aumentar a transparência e a segurança da análise da concentração e também proporcionar às partes um mecanismo preparado para eliminar de transacções que levantam pequenos problemas de concorrência.

\subsubsection{O declarante e documentação}

O Artigo 21 da LAM dispõe apenas que os operadores económicos devem declarar a concentração com antecedência, mas não deixa claro quem é obrigado pela declaração. 
Algumas melhorias na aplicação da concentração têm sido alcançadas através da legislação complementar recentemente aprovada. Para a disposição da LAM ser aplicável, as Opiniões Orientadoras do Departamento Antimonopólio do Ministério do Comércio sobre a Declaração das Concentrações de Empresas e as Medidas para a Declaração de Concentração de Empresas preveem ainda que qualquer concentração de empresas realizada por meio de aquisição deve ser declarada por qualquer empresa participante da aquisição, e qualquer concentração de empresas realizada por outros meios deve ser declarada pela empresa que tem o direito de controlar ou impor uma influência decisiva sobre a adquirida, e as outras empresas devem dar assistência. Se o obrigado pela declaração não dar a notificação às autoridades da concorrência, outros operadores económicos que participam na concentração podem fazer tal declaração. ${ }^{41}$

Em relação aos documentos e materiais, o artigo 23 da LAM especifica que as empresas devem apresentar um documento de declaração, os esclarecimentos sobre os efeitos da concentração, o acordo de concentração, os relatórios financeiros e contabilísticos do ano anterior, e outros documentos conforme exigidos pela agência de aplicação da concentração. As Opiniões Orientadoras do Departamento Antimonopólio do Ministério do Comércio sobre a Declaração das Concentrações de Empresas fornecem uma descrição detalhada de cada um dos elementos mencionados pela LAM. ${ }^{42}$ Considerando que os documentos e materiais constituem base importante para a análise de concentrações, o Departamento Antimonopólio da Mofcom formulou posteriormente algumas Opiniões Orientadoras sobre os Documentos e de Materiais de Declaração da Concentração de Operadores Económicos, para enumerar informações, tais como a definição dos mercados relevantes e as razões, as situações básicas dos mercados relevantes, o impacto da concentração sobre a estrutura do mercado, as grandes empresas à montante e à jusante, a estrutura da fornecimento e a estrutura da demanda, a análise de acesso ao mercado, o desenvolvimento industrial, os concorrentes, os consumidores, o progresso técnico, o desenvolvimento económico, e os interesses públicos. ${ }^{43}$

No entanto, merece destaque que nem a LAM, nem as duas opiniões orientadoras alguma vez estabeleceram a força probatória das explicações e informações fornecidas pelas próprias empresas ou agentes confiadas. $\mathrm{Na}$ realidade, pode ser muito difícil para um operador económico particular colectar dados sobre o mercado em causa e os impactos na estrutura do mercado de concorrência, etc., e obter apoio oficial ou assistência de associações dos sectores. Quando os agentes ou outras entidades são encarregados de fazer alguns estudos e análise de mercado numa base compensável, sua independência e credibilidade podem ser duvidosas. Até agora, os regulamentos existentes não têm sido capazes de especificar em que medida os documentos e os materiais apresentados podem servir de base para julgamentos finais das agências de aplicação da concentração. A falta de regras sobre o peso da prova pode 
encorajar o comportamento de rent-seeking (a acção dos agentes económicos com o objectivo de obter privilégios no mercado por manipulação do ambiente social ou político) e o comportamento de lobby político na China. Espera-se que mais regras a esse respeito sejam publicadas num futuro próximo.

Tem-se observado que "enquanto as submissões na UE e nos EUA também contêm os requisitos de divulgação de documentos internos, a orientação do Mofcom não contém qualquer das limitações sobre divulgação geralmente contidas em tais pedidos”. ${ }^{44}$ Não sabendo muito sobre o ónus de prova, bem como a função de prova, os operadores económicos em causa irão, provavelmente, apresentar uma quantidade muito grande de documentação para ajudar a provocar uma concentração. É inteiramente possível que todos os documentos não estejam relacionados com a análise da concentração. Essa prática pode aumentar os custos da transacção para as partes envolvidas $^{45}$ e também aumentar a tarefa das autoridades da concorrência.

\subsubsection{TIMING: DUAS FASES DO PERÍODO DE ESPERA}

Substancialmente análoga às normas dos EUA e da UE, ${ }^{46}$ a LAM impõe duas fases do período de espera. Na primeira fase, a agência de aplicação deve proceder a um exame preliminar da concentração declarada, tomar uma decisão, e notificar os operadores económicos em causa, por escrito, no prazo de trinta dias após a recepção dos documentos e materiais. ${ }^{47}$ Se a operação não pode ser liberada na primeira fase, a segunda fase iniciará. Se a agência decidir realizar um novo exame deve, no prazo de noventa dias a partir da data da decisão, concluir o exame, tomar uma decisão sobre se proíbe a concentração, e enviar a notificação por escrito. As decisões de proibir a concentração precisam ser explicadas e justificadas. Em determinadas circunstâncias, depois da notificação às partes interessadas, a agência de aplicação pode prorrogar o prazo do exame, por não mais de sessenta dias, incluindo um acordo entre as partes, a necessidade de uma verificação posterior de documentos, ou uma alteração significativa de circunstâncias. ${ }^{48}$ Em todo o caso, todo período das duas fases de análise da concentração não pode ultrapassar 180 dias. Embora a legislação não deixe claro se os períodos referem-se a “dias de calendário" ou "dias úteis", a prática do Mofcom ilustra que o método de cálculo adoptado segue "dias de calendário". 49

À luz das Opiniões Orientadoras do Departamento Antimonopólio do Ministério do Comércio sobre a Declaração de Concentrações de Empresas, a autoridade da concorrência, depois de receber a documentação, deve emitir uma Ficha de Inscrição da Informação de Declaração Antimonopólio da Concentração dos operadores económicos, mas a emissão de tal ficha de inscrição não significa, necessariamente, que a declaração da documentação preenche os requisitos legais. Como se observa, esse sistema de registo alinha o Mofcom à prática internacional através da criação de um registo central para aceitar as declarações. ${ }^{50}$ 
Independentemente das circunstâncias, o período de análise dentro de 180 dias estabelecido pela LAM é visivelmente mais curto do que o observado para muitas concentrações nos EUA e na UE. No entanto, essa vantagem de tempo estabelecida pela LAM pode ser extensivamente diluída pela prática existente introduzida pelas novas regras de execução. Na prática, o período formal de análise começa apenas com uma notificação escrita emitida pelo Mofcom mediante o recebimento de documentos e materiais completos da declaração, se o Mofcom considerar que a documentação está de acordo com as exigências legais, após uma análise inicial. ${ }^{51}$ Embora alguns profissionais tenham observado que a LAM dá uma vantagem de tempo significativa sobre as regras dos EUA para as transacções - a LAM não pune o envio de materiais incompletos das partes reiniciando o período legal de espera, enquanto as regras dos EUA permitem as agências antitrust o fazerem ${ }^{52}$ - na ausência de um calendário previsto para a análise inicial estabelecida pelas Medidas para a Declaração de Concentração de Empresas, o Mofcom, na verdade, "controla a data de início da fase I do período de análise e pode, potencialmente, prolongar significativamente o período de análise recusando-se a aceitar uma notificação como completa, atrasando assim o início da análise”. ${ }^{53} \mathrm{Na}$ realidade, o tratamento muito brando da apresentação incompleta talvez não seja viável e prático para uma agência de concorrência jovem como a China, e pode ser facilmente entendido por que as autoridades chinesas prescreveram a emissão de uma notificação por escrito como o dia de início do processo de análise. Mesmo assim, foi deixado um amplo espaço para melhorar a previsibilidade das disposições legais em vigor.

\subsubsection{O PROCESSO DEVIDO}

Após a promulgação da AML, a autoridade da concorrência chinesa formulou regras detalhadas para melhorar o processo adequado de análise da concentração. Actualmente, as empresas estão autorizadas a apresentar declarações e argumentos escritos sobre as suas notificações, e as suas declarações e os argumentos devem ser atendidos. ${ }^{54}$ Vale a pena notar que o novo regulamento formulado pelo Mofcom recupera o sistema de audiência, que não está presente na LAM. Durante o período de exame, o Mofcom pode tomar conselhos das unidades ou indivíduos, incluindo os departamentos governamentais, as associações industriais, empresas e consumidores. Os concorrentes, as empresas à montante e à jusante das indústrias, representantes de outras empresas relevantes, especialistas, representantes de associações industriais, departamentos governamentais relevantes e os consumidores podem ser convidados, conforme o caso, a participar nas audiências. ${ }^{55}$ Os procedimentos inteiros de audiências também foram definidos e os debates não estão incluídos nas audiências. ${ }^{56}$ As partes na concentração também podem enviar suas defesas por escrito relativas a quaisquer condições restritivas e fazer suas propostas para qualquer ajuste. ${ }^{57}$ 


\subsubsection{As DECISÕES FINAIS DAS AGÊNCIAS dE APLICAÇÃo}

Quando a análise chega ao fim, a transacção pode ser liberada, proibida, ou imposta por algumas soluções pelas agências de aplicação. De acordo com a LAM e as Medidas para o Exame da Concentração de Empresas, as decisões finais incluem: (1) [se] durante a primeira fase do exame, o Mofcom considerar que nenhum exame suplementar será necessário, irá, posteriormente, notificar o declarante por escrito; (2) durante a segunda fase do exame o Mofcom decide uma das seguintes opções: liberar a operação, não proibir a operação, mas utilizar algumas soluções para eliminar ou reduzir os efeitos para impedir e restringir a concorrência, ou proibir a operação. Se o Mofcom não tomar qualquer decisão dentro do prazo estabelecido, as empresas participantes na concentração podem executar a concentração. ${ }^{58}$ Até ao momento, o Mofcom só torna públicas todas suas decisões de proibição e utilização de soluções de qualquer concentração com explicações e justificações. ${ }^{59}$

\subsection{AnÁlise SubStantiva}

\subsection{Critério de anÁlise}

Muitas diferenças ainda permanecem na análise substantiva do exame da concentração entre a China e os ordenamentos jurídicos de alguns países desenvolvidos. Sabe-se que o "teste de diminuição substancial da concorrência" e o "teste de domínio" são os dois principais critérios de análise adoptados por muitos ordenamentos jurídicos. Nos EUA, o Clayton Act (1914, art. 7), proíbe as aquisições que podem resultar em redução significativa da concorrência ou a criação de um monopólio. Na UE, o Regulamento sobre Concentrações - Regulamento (CE) n. 139/2004, art. 2 - proíbe concentrações que impedem significativamente a concorrência efectiva no mercado comum, ou uma parte substancial do mesmo, particularmente como resultado da criação ou reforço de uma posição dominante. A principal crítica do critério do domínio é de que ele não se refere aos mercados oligopolistas, ${ }^{60}$ prestando mais atenção à avaliação da estrutura do mercado, mas ignorando o ambiente de concorrência dinâmica. ${ }^{61}$ Enquanto "o teste da diminuição substancial da concorrência” for mais abrangente e flexível, será difícil quantificar os critérios e, portanto, ser criticado devido à sua incerteza. ${ }^{62}$

O artigo 28 da LAM prevê que quando uma concentração tem ou é provável que tenha o efeito de eliminar ou restringir a concorrência, as autoridades da concorrência devem proibir a concentração; no entanto, se as partes na concentração podem provar que o impacto favorável da concentração supera, claramente, o impacto adverso, ou que a concentração está em harmonia com os interesses públicos, as autoridades da concorrência podem decidir não proibir a concentração. Parece que o critério de análise na China se concentra principalmente no possível efeito da concentração. A regra básica para se proibir uma operação pela agência de aplicação chinesa é que a operação tem ou é susceptível de ter o efeito de eliminar ou restringir 
a concorrência. Todavia, há duas excepções a essa regra: (1) quando o efeito favorável supera o efeito adverso; e (2) quando a concentração está em conformidade com os interesses públicos. Pode ser visto que o critério da análise substantiva na China é muito complexo e bastante singular, sendo diferente do "teste de diminuição substancial da concorrência" e o "teste do domínio".

Na China, o "domínio" será considerado pelas autoridades da concorrência, ao avaliar o efeito da concorrência, mas há outros factores a serem levados em conta. Os elementos seguintes são necessários para a análise do controlo das concentrações: (1) a quota de mercado das partes na concentração no mercado em causa e seu poder de controlo do mercado; (2) o grau de concentração do mercado; (3) o efeito da concentração sobre o acesso ao mercado e desenvolvimento tecnológico; (4) o efeito da concentração sobre os consumidores e outras empresas; (5) o efeito da concentração no desenvolvimento económico nacional; e (6) quaisquer outros factores que podem afectar a concorrência no mercado. ${ }^{63} \mathrm{Com}$ base na enumeração apresentada, apenas o primeiro elemento do artigo 27 da LAM se refere ao domínio do mercado. Em relação aos efeitos sobre o acesso ao mercado e desenvolvimento de tecnologia, consumidores e desenvolvimento económico nacional, nenhumas orientações foram ainda publicadas. Além disso, a medida em que o desenvolvimento económico nacional e a política industrial seriam ponderados na análise substantiva também é desconhecida. ${ }^{64}$

A crítica ao critério de avaliação substantiva na LAM por estudiosos chineses centra-se, principalmente, em torno da formulação não clara e imprecisa da redacção. ${ }^{65}$ O artigo 28 diz o seguinte: "Sempre que a concentração de operadores económicos venha ou possa eliminar ou restringir a concorrência, a Agência de Aplicação da Lei Antimonopólio no âmbito do Conselho de Estado deve tomar a decisão de proibir a concentração". Na verdade, qualquer operação de concentração pode, em certa medida, produzir efeitos anticoncorrenciais, e o Mofcom deve proibir a concentração, tal como exigido pela LAM. Nos ordenamentos jurídicos maduros, como dos EUA e da UE, apenas a concentração excessiva irá levantar problemas de concorrência. Para um regime de concentração jovem na China, é ilusório para as autoridades de concorrência proibir todas as concentrações sem identificar os seus níveis. Provavelmente, por estar ciente deste problema, o artigo 3 da nova versão das Disposições relativas a Concentrações e Aquisições de Empresas Nacionais por Investidores Estrangeiros de 2009 prevê que "Em concentrações e aquisições de empresas nacionais, os investidores estrangeiros (...) não devem criar concentração excessiva, eliminar ou dificultar concorrência”.

\subsubsection{Definição de mercado Relevante}

A definição do mercado relevante é, geralmente, o ponto de partida para analisar comportamentos das partes na concentração, concentração do mercado, o poder, 
as quotas, ${ }^{66}$ e um passo importante da aplicação da Lei Antimonopólio. ${ }^{67} \mathrm{Na}$ China o mercado relevante tem uma dimensão da mercadoria/produto e uma dimensão geográfica. ${ }^{68}$

Muito semelhante à designação de mercado do produto relevante da UE, ${ }^{69}$ a definição de mercado de mercadoria relevante na legislação chinesa mantém a abordagem de “intercambialidade razoável” e está baseada em factores tais como características dos produtos, preços e utilização pretendida. ${ }^{70}$ De acordo com o novo guia, o mercado de mercadoria relevante refere-se a um mercado compreendendo um grupo ou uma categoria de mercadorias que é considerado pelos consumidores como tendo uma relação de substituição relativamente forte, com base nas características, usos, e preços das mercadorias, e o mercado geográfico relevante é um âmbito de áreas geográficas em que os consumidores podem adquirir mercadorias que tenham uma relação de substituição relativamente forte. ${ }^{71}$

Na definição do mercado relevante e restrições da concorrência, a análise da substituição da procura da concorrência será essencialmente realizada, e onde a substituição da oferta constitui semelhante restrição da concorrência no comportamento do operador económico, como a substituição da procura, a substituição da oferta também deve ser tida em conta. ${ }^{72}$

No que diz respeito à substitutibilidade do lado da procura, a análise ajuda a determinar o nível de substituição entre diferentes mercadorias na perspectiva dos que procuram com base na sua procura das funções e usos das mercadorias, aprovação da qualidade das mercadorias, do preço das mercadorias, bem como a disponibilidade destas. ${ }^{73}$ É de salientar que, com base nas referências da UE, ao definir o mercado relevante, as autoridades chinesas da concorrência decidem também considerar "as evidências mostrando que a mudança de demandantes ou consideração de mudança para outras mercadorias/áreas geográficas para comprar mercadorias devido a mudanças no preço ou qualquer outro factor competitivo das mercadorias". ${ }^{74}$

Em relação à substituição na oferta, ela visa determinar o nível de substituição entre diferentes mercadorias na perspectiva dos operadores económicos. Quanto menor for o investimento que o outro operador económico faz na renovação das instalações de produção, menores são os riscos estranhos que ele irá suportar; também, quanto mais rápido a substitutos próximos são fornecidos, maior será o nível de substituição da oferta. ${ }^{75}$

Semelhante a muitas jurisdições, o teste do monopolista hipotético (o chamado "pequeno mas significativo e não transitório aumento de preços" ou teste SSNIP) 76 foi também adoptado pelas autoridades chinesas da concorrência como um método analítico, quando o âmbito do mercado dentro do qual os operadores económicos concorrem uns com os outros não é claro ou é difícil de determinar. A análise vai ajudar a definir o mercado relevante quando o monopolista hipotético tem lucro a fazer após continuamente (normalmente um ano) aumentar o preço das mercadorias 
relevantes na mercadoria alvo ou na área geográfica alvo em pequena medida (normalmente $5 \%$ a $10 \%) .{ }^{77} \mathrm{Na}$ China, o teste do monopolista hipotético também pode ser aplicado ao abuso de posição dominante no mercado e conluio, além dos casos de concentração, que é muito semelhante à prática da UE. ${ }^{78}$

\subsubsection{Definição de Quota de mercado e níveis de CONCEnTração}

Até agora, as autoridades chinesas da concorrência não formularam quaisquer regras para avaliar a quota de mercado, medir os níveis de concentração (p.ex., HerfindahlHirschman Index, HHI), e determinar o efeito da concentração sobre o acesso ao mercado e desenvolvimento de tecnologia.

\subsubsection{Defesas e testes isentos}

Actualmente, as autoridades chinesas da concorrência aceitam defesas de eficiência e defesas de interesses públicos. Esses dois tipos de defesa contra os efeitos anticoncorrenciais são enumerados no mesmo artigo. O teste isento na análise de concentrações na China está prescrito no artigo 28 da LAM, “se os operadores económicos em causa poderem provar que o impacto favorável da concentração sobre a concorrência ultrapassa claramente o impacto adverso, ou que a concentração está em harmonia com os interesses públicos, o Departamento de Aplicação da Lei Antimonopólio do Conselho de Estado pode decidir não proibir a concentração”.

No entanto, o Mofcom não formulou e anunciou quaisquer directrizes para definir os requisitos de eficiência económica e interesses públicos. ${ }^{79}$ Tendo em conta as legislações de muitos países emergentes, é bastante difícil excluir a noção de interesse público das suas leis antitrust. Os objectivos da legislação serão afectados pelo grau de liberalização do mercado e os níveis de desenvolvimento económico. As defesas de interesses públicos irão proporcionar uma oportunidade para equilibrar a política de concorrência e a política industrial. O grande desafio para a agência de aplicação chinesa é como definir claramente os principais factores de interesses públicos e tornar as disposições legais aplicáveis.

Por outro lado, ao contrário das legislações dos EUA e da UE, ${ }^{80}$ a defesa de empresa em insolvência não foi formalmente aceite pelas autoridades de aplicação chinesas. Com base nas Opiniões Orientadoras do Mofcom, se a operação de concentração envolve falências de empresas, as partes deverão fornecer explicações especiais. ${ }^{81} \mathrm{Na}$ realidade, no contexto da transição económica e reestruturação das empresas, as falências e aquisições já se tornaram uma ferramenta importante para optimizar a alocação de recursos de mercado na China. A autoridade da concorrência tem de ter em mente como dar devida importância às empresas em insolvência na promoção de eficiências económicas e da concorrência e, ao mesmo tempo, evitar efeitos anticoncorrenciais como consequência da mudança da estrutura do mercado. 


\subsubsection{OUtros Critérios de NÃo CONCORRÊNCIA}

\subsubsection{A POLÍtICA INDUSTRIAL}

Os critérios de não concorrência também têm sido considerados pelo regime das concentrações da China. A política de concorrência está intimamente relacionada com política industrial e tem-se observado que essas duas políticas contradizem-se, e o conflito de interesses tornar-se-á cada vez mais claro. ${ }^{82}$ Apesar de as Empresas Estatais (EEs) estarem se afastando de algumas das indústrias mais competitivas, elas continuam concentradas em outras indústrias com um monopólio estatal e os lucros continuando a aumentar (incluindo petróleo e carvão). ${ }^{83}$ "As EEs têm vindo a beneficiar desproporcionalmente de medidas recentes do governo para impulsionar a economia, especialmente o estímulo económico." ${ }^{84}$ Em contraste com as normas adoptadas por outros ordenamentos jurídicos, em que a política de concorrência prevalece sobre outros sectores económicos, ${ }^{85}$ o artigo 7 da LAM defende as EEs que detêm uma posição dominante na economia e actuam sobre a segurança nacional, ou que operam com direitos exclusivos concedidos pelo Governo. A LAM protege as actividades legítimas das EEs, e também as obriga a cumprir as leis e regulamentos e a não prejudicar os consumidores. Através de um compromisso entre a política industrial e a política de concorrência, ${ }^{86}$ o legislador chinês apoia, por um lado, os campeões nacionais e os seus papéis de liderança na economia nacional, enquanto, por outro lado, trá-los em conformidade com a reforma dos sectores monopolistas, introduzindo o mecanismo da concorrência e uma supervisão eficaz. No momento, não há previsão detalhada na legislação sobre a consideração dos campeões nacionais e da política industrial.

Quando comparada com a prática internacional, a muito ampla lista de considerações na LAM causa preocupação, pois pode criar imprevisibilidade da análise de concentrações. Ao contrário do consenso internacional (p.ex., a Rede Internacional da Concorrência), ${ }^{87}$ a análise de concentrações antitrust na China não se concentra exclusivamente em concentrações anticoncorrenciais e pura análise económica. Ela é usada para perseguir outros objectivos, conforme previsto no artigo 1 da LAM. Como comentado por Eleanor Fox, a China é um país em desenvolvimento, o que pode exigir-lhe tomar uma perspectiva ligeiramente diferente em casos próximos do que os EUA e a UE. ${ }^{88}$ As considerações de interesses públicos, políticas industriais e desenvolvimento económico nacional são compreensíveis no actual estágio de transição económica da China. Deve-se ter notado que após o surgimento da crise mundial de crédito, existiram apelos de jurisdições maduras que as autoridades de concorrência devem responder às preocupações mais amplas do que a concorrência. ${ }^{89}$ Como observou Wu Lifen, "uma escolha cautelosa quanto à extensão em que o controlo das concentrações chinesas estará focada, a concorrência seria justificada tendo em vista o surgimento no Reino Unido da provável necessidade de uma análise mais ampla da concorrência”. 90 


\subsubsection{ANÁLISE DE SEGURANÇA NACIONAL}

Outro exemplo notável de questões de não concorrência é a segurança nacional. De acordo com a LAM, sempre que um investidor estrangeiro participar na concentração por fusão ou aquisição de empresas nacionais ou por qualquer outro meio, e estiver envolvida a segurança nacional, além da análise de concentrações, é também necessário a análise de segurança nacional. ${ }^{91} \mathrm{O}$ Mofcom exige notificações sempre que a concentração de uma empresa nacional por um investidor estrangeiro envolve qualquer indústria crítica, afecta ou pode afectar a segurança da economia nacional, ou causa a transferência de controlo real sobre a empresa nacional que possui uma marca de renome ou uma marca há muito prestigiada da China. ${ }^{92}$ Muito recentemente, em 2 de março de 2011, o Conselho de Estado anunciou o Regulamento sobre Análise de Segurança da Concentração ou Aquisição de Empresas Nacionais por Investidores Estrangeiros, e logo depois, o Mofcom formulou regras provisórias com o objectivo da aplicação desse Regulamento sobre Análise de Segurança.

Como principal destinatário do investimento directo estrangeiro (IDE) nos países em desenvolvimento, a China mantém sua liderança com a maior absorção de IDE por dezoito anos consecutivos. ${ }^{93}$ No ano de 2010, o capital estrangeiro absorvido pela China atingiu US\$ 100 biliões. ${ }^{94}$ Desde os anos 1990, novas regras internacionais de comércio e investimento têm restringido a liberdade dos governos nacionais, e muitos governos são incentivados a fornecer um ambiente eficiente para as empresas baseadas no mercado funcionarem. O Relatório da Unctad apontou: "Se os adquirentes são oligopolistas globais, eles podem muito bem vir a dominar o mercado local. Eles podem levar as empresas estratégicas ou mesmo indústrias inteiras caírem sob controlo estrangeiro, ameaçando capacitação empresarial e tecnológica locais". 95 À semelhança das preocupações de outros países em desenvolvimento, o governo chinês preserva um espaço político para se certificar de que o IDE e as concentrações estrangeiras beneficiam o desenvolvimento nacional. A melhoria constante do ambiente doméstico de investimento na China constitui um novo motor para o desenvolvimento estável na atracção de investimentos estrangeiros de todo o mundo. Até à data, tem sido formado o regime chinês em relação a concentrações estrangeiras, que contém análise antimonopólio, análise de segurança nacional e análise de entrada. ${ }^{96}$

O regulamento recentemente publicado em 2011 define o âmbito da análise de segurança de concentrações e aquisições de investidores estrangeiros, nomeadamente, empresas domésticas da indústria militar e empresas militares de apoio, empresas em torno das grandes e sensíveis instalações militares e outras entidades relacionadas com a defesa da segurança nacional, produtos agrícolas, energia e recursos essenciais, instalações de infraestrutura importantes, serviços de transporte, tecnologias-chave, e fabrico de equipamentos primordiais, que estão relacionados com a segurança nacional e cujo real poder de controlo pode ser obtido por investidores estrangeiros. ${ }^{97}$ Parece que os controlos permanecem apenas em alguns sectores sensíveis à 
segurança nacional. Embora a LAM não forneça conteúdo detalhado da análise de segurança, o regulamento de 2011 estipula que as influências sobre as defesas de segurança nacional, o funcionamento estável da economia nacional, a ordem da vida social básica, e a capacidade de pesquisa e desenvolvimento de tecnologias-chave que envolvam segurança nacional serão analisadas. ${ }^{98}$ Tanto o mecanismo como os procedimentos foram formulados. O Mofcom é membro da reunião ministerial conjunta para a análise de segurança. ${ }^{99}$

Com a promulgação do regulamento sobre a análise de segurança, uma das lacunas que permanecia na implementação da LAM foi preenchida. A promulgação do Regulamento sobre Análise de Segurança é conducente à definição das vagas disposições legais da LAM e ao melhoramento da transparência da avaliação substancial, porque a análise de concentrações antitrust é diferente da análise de segurança nacional em termos de objectivos, âmbito, critérios e procedimentos. A análise de segurança será executada em paralelo com a análise de concentrações antitrust.

\subsection{SOluÇões}

Nos termos do artigo 29 da LAM e do artigo 11 das Medidas para o Exame de Concentração de Empresas, o Mofcom tem o poder para liberar ou bloquear uma concentração. Durante o processo de análise, quando uma concentração suscita preocupações de concorrência, as partes podem oferecer condições restritivas, ajustando o plano da operação e o Mofcom pode impor soluções antes de ser concedida a liberação. As soluções incluem três tipos: condições estruturais (incluindo a privação de activos ou negócios parciais); as condições de comportamento (incluindo a concessão de acesso às infraestruturas como rede ou plataforma, licenciamento de tecnologias-chave e extinção de acordos de exclusividade entre as partes); e as condições híbridas que combinam as duas.

Desde a promulgação da LAM, o Mofcom bloqueou um caso ${ }^{100}$ e impôs soluções para seis concentrações. ${ }^{101}$ Excepto para a operação GM/Delphi, em que a autoridade da concorrência impôs uma solução pura de comportamento, foi essencialmente utilizada uma solução estrutural (incluindo a alienação de activos ou negócios). No ano de 2010, o Mofcom recebeu mais de 130 notificações de concentrações, das quais cerca de 120 operações foram aceites, ${ }^{102}$ a apenas um operação ${ }^{103}$ foram impostas condições, e as outras foram liberadas. Quando comparada com a primeira decisão da análise da concentração do Mofcom relativa a Inbev / Anheuser Busch, após a promulgação da LAM, as decisões recentemente tomadas são mais transparentes, com amplas justificações. Como se pode ver, a grande maioria dos registos de concentrações foi liberada sem condições.

\subsection{SANÇÕES}

Sempre que um operador económico implementar uma concentração em violação da LAM (p.ex., a obrigação de notificação da concentração não foi cumprida, as partes 
executaram a concentração antes de obter qualquer decisão da órgão de aplicação, as partes apresentaram documentação falsa, etc.), o Mofcom deve mandá-lo interromper a concentração, alienar acções ou activos, transferir o negócio, ou adoptar outras medidas necessárias para restaurar a situação do mercado antes da concentração dentro de um prazo, e pode impor uma multa de até 500 mil yuans (aproximadamente US\$ $78 \mathrm{mil})$.

O sistema legal chinês apenas prevê sanções administrativas por infracções relativas ao controlo das concentrações. A pena máxima de 500 mil yuans não parece ter força de dissuasão suficiente. ${ }^{104} \mathrm{Na}$ prática, também é difícil restaurar a situação do mercado após a concentração ilegal ter sido executada.

\section{OBSERVAÇÕES FINAIS}

\section{LACUNAS DO REGIME DE CONTROLO DE CONCENTRAÇÕES}

A comparação das diferenças entre a LAM e outras leis de jurisdições mais avançadas demonstra que o regime chinês apresenta algumas lacunas a serem colmatadas.

Em primeiro lugar, devem ser providenciadas melhores definições para termos ambíguos existentes na LAM, para aumentar a sua aplicabilidade e previsibilidade da sua implementação. Segundo, a agência de aplicação de concentrações deve interpretar a LAM cautelosamente para evitar a excessiva e indesejável discricionariedade governamental nas análises antimonopólio. Terceiro, a jovem agência precisa aumentar a transparência quando realiza as suas avaliações e tira as suas conclusões.

\section{UMA ABORDAGEM DE CONVERGÊNCIA SUAVE COM FLEXIBILIDADE}

Desde as últimas duas décadas, as concentrações e aquisições nacionais e transfronteiriças têm sido uma parte da vida económica. A concorrência ideal se tornará um bem público internacional num mundo globalizado. Para ser capaz de compartilhar esse bem público internacional, um quadro regulamentar adequado e uma execução eficaz devem ser colocados em prática. Devido ao princípio da extraterritorialidade, a LAM também se aplica a actividades fora do território da China. A extraterritorialidade da China é para ser conseguida principalmente através da cooperação internacional na política da concorrência. ${ }^{105}$ Como se sabe, na esfera de concentrações e aquisições, "mesmo subtis diferenças legais entre jurisdições criam um potencial significativo de conflito”. ${ }^{106}$ Existe uma necessidade real de reduzir as potenciais tensões e harmonizar as normas legais de diferentes jurisdições. Para uma agência de aplicação jovem sem antecedentes significativos, como a China, talvez a adopção de uma atitude cautelosa e a doutrina da cortesia ${ }^{107}$ estejam no seu melhor interesse. As regras de concorrência de jurisdições diferentes compartilham alguns valores normativos universais semelhantes; no entanto, devido a diferentes estágios de desenvolvimento, necessidades sociais 
e sistemas económicos e legais, estão sujeitas a muitas restrições causadas por diferentes ideias e objectivos. As autoridades nacionais da concorrência devem fazer adaptações, ${ }^{108}$ balançando entre convergência e flexibilidade.

A LAM e a sua aplicação da concentração reflectem alguns desafios dos países emergentes. Conforme discutido anteriormente, a LAM é inspirada por algumas jurisdições maduras (em grande parte pela lei da concorrência da UE), e a lei da UE pode ter uma certa influência orientadora sobre a sua implementação no futuro. ${ }^{109}$ Sob uma "abordagem de desenvolvimento", em vez de uma pura "abordagem da eficiência”, a China está fazendo esforços para realizar uma convergência suave com as normas internacionais, enquanto a abordagem gradual de convergência dá à China a flexibilidade para parar, ajustar e fazer uma excepção sempre que necessário.

No que diz respeito à aplicação de concentrações, numa perspectiva processual, a legislação chinesa parece estar em consonância com os princípios e procedimentos de análise de concentrações adoptados por muitas jurisdições. Pode-se ver que as autoridades chinesas da concorrência introduziram um grande número de legislação complementar para melhorar o processo devido, a clareza e a certeza das disposições legais. No entanto, mais diferenças ainda permanecem na avaliação substantiva. As agências chinesas são cautelosas a implementar a LAM, que é sensível ao estado actual da economia chinesa, usando o Direito da Concorrência como um instrumento flexível para alcançar uma diversidade de objectivos.

Em última análise, a convergência da política da concorrência chinesa com as normas internacionais vai depender da competência das autoridades de aplicação. Desde o primeiro caso de análise de concentração (Inbev/Anheuser Bush) e a primeira concentração bloqueada (Coca-Cola/Huiyuan) até a aquisição da Alpha V/Savio, o Mofcom tem tentado afincadamente encontrar um caminho adequado para atingir a verdadeira convergência.

\section{RUMO DA POLÍTICA CONCORRENCIAL CHINESA}

Como um novo participante do clube do Direito da Concorrência e uma grande potência económica, o regime do direito da concorrência da China e sua aplicação atraem a atenção de todo o mundo. Espera-se que a China se torne um participante importante na convergência internacional, compartilhando suas experiências e aplicando o aprendizado dos outros ao seu próprio dispositivo de aplicação. ${ }^{110}$

A viagem para essa agência jovem ainda é longa e vai demorar mais tempo para a China desenvolver a capacidade de aplicação efectiva. ${ }^{111}$ Conforme descrito por Gal, ${ }^{112}$ "na ecologia de antitrust nos países em desenvolvimento, a ideologia socioeconómica é o solo, as condições institucionais e organizacionais são o sol e água e as condições da economia política são pesticidas, que são necessários para o Direito da Concorrência florescer”. A aplicação da concorrência é uma parte da reforma do mercado na China. Para uma economia de transição, onde o controlo do Estado está generalizado e o nível 
de concentração da economia é relativamente baixo, as autoridades de aplicação da concorrência devem prestar atenção à defesa da concorrência ao criar um clima conducente ao desenvolvimento social. Num contexto particular na China, onde a economia planificada está se transformando na economia de mercado, a situação do mercado e as actividades são imaturas e instáveis; muitas incertezas permanecem para as políticas macroeconómicas e medidas microeconómicas. O critério de análise de concentrações deve tomar em consideração a sua adaptabilidade e as características de uma economia de transição. As leis da concorrência da China não devem apenas cumprir as missões das leis antitrust de muitas jurisdições maduras, mas também realizar as tarefas de desenvolver e melhorar um mecanismo de mercado são. Em longo prazo, há uma necessidade crítica das agências de aplicação da China fomentarem um mercado independente com menos controlo estatal, aperfeiçoar a supervisão reguladora, e melhorar os sistemas jurídicos. Num mundo de interdependência, tanto os países desenvolvidos como a China precisam aprender como harmonizar os regulamentos existentes e escapar da mentalidade de patriotismo local.

: ARTIGO APROVADO (01/06/2012) : RECEBIDO EM 22/08/2011

\section{NOTAS}

1 PANITCHPAKDI, Supachai (2010), Opening Address of the Sixth UN Conference to Review all Aspects of the Multilaterally Agreed Equitable Principles and Rules for the Control of Restrictive Business Practices, Geneva, 8-12 November 2010. Disponível em: www.unctad.info/en/6th-UN-Conference-onCompetition-Policy/Conference/Opening-Address-by-Secretary-General-of-UNCTAD/.

2 HU, Angang (2004), China: New Development Strategy, Hang Zhou, Zhejiang People Press, p. 104.

3 HAMP-LYONS, Christopher, "The Dragon in the Room: China's Anti-Monopoly Law and International Merger Review”, Vanderbilt Law Review, v. 62, n. 5, p. 1596.

4 DABBAH, Maher M. (2007), "The Development of Sound Competition Law and Policy in China: an (Im)possible Dream?” World Competition: Law and Economics Review, v. 30. n. 2, p. 345.

5 GERBER, David J. (2008), "Economics, Law \& Institutions: The Shaping of Chinese Competition Law”, Washington University Journal of Law \& Policy, v. 26, p. 284.

6 FURSE, Mark (2007), "Competition Law Choice in China”, World Competition: Law and Economics Review, v. 30 n. 2, p. 325.

7 CARDOZO, Maria Izabel Andrade Lima (2007), "A Recepção de Direitos no Sistema Brasileiro de Defesa da Concorrência”, Direito, Estado e Sociedade, n. 30, p. 204, jan./jun. 
9 Por exemplo, o $\$ 4$ do prefácio do Regulamento n. 139/2004 do Conselho, de 20/01/2004, relativo ao controlo das concentrações de empresas (Regulamento das concentrações comunitárias), dispõe: “"Tais reestruturações deverão ser apreciadas de modo positivo, na medida em que correspondam às exigências de uma concorrência dinâmica que contribui para aumentar a competitividade da indústria europeia, para melhorar as condições do crescimento e para elevar o nível de vida na Comunidade”. O § 23 estabelece ainda que "a Comissão deverá enquadrar a sua apreciação no âmbito geral da realização dos objectivos fundamentais referidos no art. 2 do Tratado que institui a Comunidade Europeia e no art. 2 do Tratado da União Europeia”.

10 Secretaria de Direito Económico da Comissão de Sistemas Jurídicos da Comissão Permanente do Congresso Nacional Popular (2007), Anotação à LAM, Explicação dos Fins Legislativos e as Disposições Pertinentes, (em chinês), Peking University Press. O legislador chinês referiu-se às Leis da Concorrência da Rússia, Brasil, Índia, e muitas economias emergentes e em transição.

11 United Nations Conference on Trade and Development (2010), Model Law on Competition, New York and Geneva, TD/RBP/CONF.7/8.

12 WANG, Xiaoye (2008), "Comments on the Chinese New Anti-Monopoly Law. "In: WANG, Xiaoye, QIU, Ben. (Ed.) New Developments of Economic Law. Beijing: China Social Sciences Press, p. 62.

13 KALlaY, Dina (2008), “China's New Anti-Monopoly Law: An International Antitrust Convergence Perspective", Remarks delivered at Melbourne Law Schools, "Unleashing the Tiger? Competition Law in China and Hong Kong” Conference, disponível em: www.ftc.gov/ioa/speeaches/081004kallaymelbourne.pdf.

14 TREBILCOCK, Michael J.; IACOBUCCI, Edward M. (2010), "Designing Competition Law Institutions: Values, Structure, and Mandate,” Loyola University Chicago Law Journal, v. 41, p. 459-464. No modelo judicial bifurcado, a autoridade tem o poder de investigação e deve propor acções de execução perante os tribunais de competência genérica, com direitos de recurso para os tribunais gerais de recurso; no modelo de agência bifurcado, a autoridade tem o poder de investigação e deve propor acções de execução perante autoridades de adjudicação especializada da concorrência, com direitos de recurso para as instâncias especializadas de recurso ou tribunais gerais de recurso, e no modelo de agência integrado, a autoridade tem o poder de investigação e julgamento, com direitos de recurso para as instâncias gerais ou especializadas de recurso.

$15 \mathrm{Na}$ UE, a Comissão Europeia tem poderes para investigar e julgar quaisquer potenciais práticas anticoncorrenciais e fusões que possam influenciar o comércio entre os Estados-membros. Ver Regulamento (CE) n. $1 / 2003$, de 16/12/2002, sobre a aplicação das regras de concorrência estabelecidas nos arts. 81 e 82 do Tratado, e o Regulamento (CE) n. 139/2004, de 20/01/2004, sobre o controlo de concentrações de empresas.

16 Arts. 9 e 10 da LAM.

17 EMCH, Adrian; HAO, Qian, (2007), “The New Chinese Anti-Monopoly Law - An Overview”, ESapience Center for Competition Policy. Disponível em: http://ssrn.com/abstract=1030451.

18 Art. 50 da LAM.

19 Veja o relatório em chinês. Disponível em: http://finance.qq.com/a/20101030/000093.htm.

20 De acordo com a LAM e as Disposições do Conselho Estadual sobre os Limiares para a Notificação Prévia de Concentrações de Empresas, o Ministério do Comércio formulou as Medidas para o Cálculo do Volume de Negócios para a Declaração da Concentração Empresarial no Sector Financeiro em conjunto com o Banco Popular da China, a Comissão Regulação Bancária da China, a Comissão Reguladora de Valores Mobiliários da China e a Comissão Reguladora de Seguros da China. O Despacho entrou em vigor a 15/08/2009.

21 Este Regulamento foi revisto em 2009 para substituir as versões anteriores de 2003 e 2006, que regiam exclusivamente as aquisições de empresas nacionais por investidores estrangeiros. Mais especificamente, algumas disposições relativas à análise de concentrações nos antecessores da revisão de 2009 foram removidas. 
A alteração em 2009 foi para assegurar a coerência com LAM e as Disposições do Conselho do Estado sobre os Limiares para a Notificação Prévia de Concentrações de Empresas.

22 Esta Directriz é encontrada apenas em Chinês. Disponível em: http://fldj.mofcom.gov.cn/ aarticle/xgxz/200902/20090206034057.html.

23 United Nations Conference on Trade and Development (2010), TD/RBP/CONF.7/L.6, p.5.

24 A LAM e a demais legislação complementar da China não distinguem joint ventures corporativas de joint ventures cooperativas.

25 Art. 20 da LAM e art. 3 das Medidas para a Declaração de Concentração de Empresas.

26 Art. 2 das Disposições sobre Concentrações e Aquisições de Empresas Nacionais por Investidores Estrangeiros de 2006.

27 Ver art. 217 da Lei das Sociedades Comerciais da China. A obtenção de poder de controlo real por um investidor estrangeiro é clarificado pelo art. 4 do Aviso da Secretaria Geral do Conselho de Estado sobre a Criação do Sistema de Análise de Segurança para Concentrações e Aquisições de Empresas Nacionais por Investidores Estrangeiros, aprovado em 02/03/2011, que adopta a mesma abordagem.

28 Veja o Capítulo $1 \S 18$ do Decreto de Aperfeiçoamento de Antitrust Hart-Scott-Rodino .

29 CALVANI, Terry; ALDERMAN, Karen, (2010), "BRIC in the International Merger Review Edifice", Cornell International Law Journal, n. 43, p. 92.

30 Art. 3 das Disposições do Conselho do Estado sobre os Limiares para a Notificação Prévia de Concentrações de Empresas.

31 Regulamento (CE) n. 139/2004, o art. 1 dispõe que “"o volume de negócios total à escala mundial pelo conjunto das empresas em causa for superior a 5.000 milhões de euros e o volume de negócios total realizado individualmente na Comunidade por pelo menos duas das empresas em causa for superior a 250 milhões de euros ".

32 Art. 2 da LAM.

33 CALVANI, Terry; ALDERMAN, Karen, (2010), op. cit., p. 93.

34 Art. 51 das Disposições sobre Concentrações e Aquisições de Empresas Nacionais por Investidores Estrangeiros de 2006.

35 Art. 22 da LAM e art. 3 das Disposições do Concelho do Estado sobre os Limiares para a Notificação Prévia da Concentração de Empresas.

36 Veja o Decreto de Aperfeiçoamento do Antitrust Hart-Scott-Rodino e o Regulamento (EC) $n$. $139 / 2004$, art. 4 , respectivamente.

37 Art. 21 da LAM.

38 Art. 16 das Medidas para a Declaração de Concentração de Empresas.

39 Arti. 8 das Disposições do Concelho de Estado sobre os Limiares da Notificação Prévia de Concentrações de Empresas.

40 Art. 1 das Opiniões Orientadoras do Departamento Anti-monopólio do Ministério do Comércio sobre a Declaração de Concentrações de Empresas.

41 Art. 2 das Opiniões Orientadoras e art. 9 das Medidas. 
42 Art. 8 das Opiniões Orientadoras do Departamento Antimonopólio do Ministério do Comércio sobre a Declaração de Concentrações de Empresas.

43 Arts. 4-8 das Opiniões Orientadoras sobre Documentos e Materiais da Declaração para a Concentração de Operadores Económicos.

44 CALVANi, Terry. Alderman, Karen, (2010), op. cit., p. 109.

45 Os documentos e materiais apresentados devem estar em chinês, de acordo com o art. 10 das Opiniões Orientadoras do Departamento Antimonopólio do Ministério do Comércio sobre a Declaração de Concentrações de Empresas.

46 Veja 15 U.S.C § 18a (b), Regulamento (EC) n. 139/2004 e o Regulamento 802/2004, de 21/04/2004, de Implementação do Regulamento (EC) n. 139/2004 relativo ao Controlo de Concentrações de Empresas.

47 Art. 25 da LAM.

48 Art. 26 da LAM.

49 CALVAni, Terry. Alderman, Karen, (2010), op. cit., p. 103.

50 Idem, ibidem.

51 Art. 14 das Medidas para a Declaração de Concentração de Empresas.

52 ANDREW, Lee, (2008), "International Issues: China's Anti-Monopoly Law: Introduction to New Merger Control Regime and Other Unresolved Issues”. Disponível em: www. whitecase.com.

53 CALVANI, Terry. ALDERMAN, Karen, (2010), op. cit., p. 104.

54 Medidas para o Exame da Concentração de Empresas, art. 5.

55 Idem, art. 7.

56 Idem, art. 8.

57 Idem, arts. $10(1)$ e 11.

58 Idem, arts. 9 e 14.

59 Art. 30 da LAM.

60 LITZELL, Maria, (2005), "The Appraisal of Collective Dominance Under the Clarified Substantive Test of the New EC Merger Regulation: A Step Towards Greater Global Convergence of Merger Control?” 1 Eur. Law Student Ass'n Selected Papers on Eur. Law, 32, p. 41.

61 SHI, Jiansan; QIAN, Shiyu, (2009), "Study on Chinese Substantive Examination Standard on Concentration of Undertakings from an International Perspective”. China Management Studies, v. 4, n. 4, p. 158.

62 Idem, ibidem.

63 Art. 27 da LAM.

64 FURSE, Mark, (2007), op. cit., p. 334.

65 Veja, p.ex., WANG, Xiaoye, (2008), "Analysis on the Concentration of Undertakings of Chinese AntiMonopoly Law”, Law Magazine, n. 1. Disponível em: www.antimonoplylaw.org/article/default. asp?id=1461. 
66 Art. 2 da Directriz do Comité Antimonopólio do Concelho de Estado para a Definição de Mercado Relevante.

67 As Orientações das Concentrações Horizontais dos EUA, do Departamento de Justiça dos EUA e da Comissão de Federal Comércio dispõem: "A análise das agências não precisa começar com a definição do mercado. Algumas das ferramentas de análise utilizadas pelas agências para avaliar os efeitos da concorrência não dependem da definição do mercado, embora a avaliação das alternativas competitivas disponíveis para os clientes seja sempre necessária em algum momento na análise”, versão de 19/08/2010, p. 7.

68 Art. 12 da LAM dispõe que ““o termo Mercado relevante refere-se ao âmbito da mercadoria ou âmbito territorial dentro ao qual os operadores económicos concorrem entre eles durante um certo período de tempo para mercadorias ou serviços específicos”“.

69 Aviso da Comissão sobre a Definição do Mercado Relevante para efeitos da Lei da Concorrência da Comunidade. Jornal Oficial: OJC 372, 9 dez. 1997.

70 “'Um mercado do produto relevante compreende todos aqueles produtos e/ou serviços que sejam considerados intercambiáveis ou substituíveis pelo consumidor, devido às características dos produtos, seus preços e seus usos previstos”“, em Aviso da Comissão sobre a Definição do Mercado Relevante para efeitos da Lei da Concorrência da Comunidade.

71 Directriz do Comité Antimonopólio do Concelho de Estado para a Definição de Mercado Relevante, art. 3.

72 Idem, art. 4.

73 Idem, art. 5.

74 Idem, art. $8(1)$

75 Idem, art. 6.

76 No Aviso da Comissão sobre a Definição do Mercado Relevante para efeitos da Lei da Concorrência da Comunidade, a expressão usada é “"hipotética mudança pequena, não transitória nos preços relativos”“".

77 Directriz do Comité Anti-monopólio do Concelho de Estado para a Definição de Mercado Relevante, art. 10 .

78 Ver art. 11 da Directriz do Comité Anti-monopólio do Concelho de Estado para a Definição de Mercado Relevante e o Aviso da Comissão sobre a Definição de Mercado Relevante par efeitos da Lei da Concorrência da Comunidade. Jornal Oficial: OJC 372, 9 dez. 1997.

79 A antiga versão das Disposições relativas a Concentrações e Aquisições de Empresas Nacionais por Investidores Estrangeiros de 2006 previa no ar. 54 que as partes poderão solicitar a isenção de análise da concentração em qualquer das seguintes circunstâncias: (1) a aquisição pode melhorar a condição para uma concorrência leal no mercado; (2) uma empresa deficitária é adquirida e o emprego é assegurado; (3) a aquisição ajuda a absorção de tecnologias avançadas e gestão de pessoal, e é capaz de melhorar a competitividade internacional da empresa; ou (4) a aquisição pode melhorar o ambiente. Todavia, este artigo foi suprimido na revisão de 2009.

80 Veja as orientações sobre a avaliação das concentrações horizontais do Regulamento do Concelho sobre o controlo das concentrações de empresas, 2004/C, 31/03, 05/02/2004 (secção VIII) e as orientações para concentrações Horizontais do Departamento de Justiça e Comissão Federal do Comercio dos EUA, de 19/08/2010 (secção 11).

81 Opiniões Orientadoras do Departamento Antimonopólio do Ministério do Comércio sobre os documentos e materiais da Declaração das Concentrações de Empresas, art. 18. 
82 GAllowAY, Jonathan, (2007), "The Pursuit of National Champions: The Intersection of Competition Law and Industrial Policy”. European Competition Law Review, v. 28 n. 3, p. 186.

83 Trade Policy Review of China Report by the Secretariat, (2010), WT/TPR/230, p. 54-55.

84 Idem, p. 31.

85 NING, Guobin, (2007), “The Status of Antimonopoly Enforcement Agencies.” Legal System and Society, v. 12, p. 235.

86 OECD, (2009), The Challenges of Transition for Competition Law and Policy in China, p. 22.

87 International Competition Network, (2008), Recommended Practices for Merger Analysis, § 1(A), cmt 1, disponível em: www.internationalcompetitionnetwork.org/media/library/Cartels/Merger_WG_1.pdf.

88 FOX, Eleanor M, (2007), “Economic Development, Poverty, and Antitrust: The Other Path". 13 SW J.L \& Trade AM, p. 211.

89 FREEMAN, Peter, (2008), "Is Competition Everything?", speech at Law Society European Group. Disponível em: www.competition-commission.org.uk/our_role/speeches/pdf/freeman_law_society_210708.pdf.

90 WU, Lifen, (2010), "Anti-monopoly, National Security and Industrial Policy: Merger Control in China”. World Competition: Law and Economics Review, v. 33, n. 3, p. 496, Sep.

91 Art. 31 da LAM.

92 Disposições sobre Concentrações e Aquisições de Empresas Nacionais por Investidores Estrangeiros de 2009 , art. 12

93 Estatísticas do Mofcom. Disponível em: http://211.154.136.153/ss/?action-viewnews-itemid244932.

94 Ver http://finance.jrj.com.cn/2011/01/1820169019103.shtml.

95 UNCTAD, (2000), World Investment Report 2000 Cross-border Mergers and Acquisitions and Development, New York and Geneva, p. xxiii.

96 Ver Catálogo de Orientação Industrial de Investimento Estrangeiro de 2009 que entrou em vigor a $01 / 12 / 2007$.

97 Regulamento sobre Análise de Segurança da Concentração e Aquisição de Empresas Nacionais por Investidores Estrangeiros, art. 1 (1)

98 Idem, art. 2.

99 Idem, arts. 3 e 4.

100 Coca-Cola/Huiyuan, ver decisão do Mofcom, de 18/03/2009. Disponível em: http://fldj.mofcom.gov.cn/aarticle/ztxx/200909/20090306108494.html

101 São elas: Inbev/Anheuser Busch, Mitsubishi/Lucite, GM/Delphi, Pfizer/Wyeth, Panasonic/Sanyo, Novartis/Alcon. Dsponível em http://fldj.mofcom.gov.cn.

102 Disponível em: www.antimonopolylaw.org/article/default.asp?id=2587.

103 Novartis/Alcon, veja a decisão do Mofcom datada de 13/08/2010. Disponível em: http://fldj.mofcom.gov.cn/aarticle/ztxx/201008/20100807080639.html. 
104 WANG, Xiaoye, (2008), "Analysis on the Concentration of Undertakings of Chinese Anti-Monopoly Law.” Law Magazine, 1, disponível em: www.antimonoplylaw.org/article/default.asp?id=1461 .

105 Art. 2 da LAM. A China tem participado de actividadeso relacionadas com políticas de concorrência da Apec, OCDE, Unctad e OMC. Bilateralmente, a Saic e o Mofcom assinaram acordos de cooperação. A China entra também em trocas e cooperação com autoridades da concorrência da União Europeia, Japão, República da Coreia e Estados Unidos. Estes incluem o Diálogo da Política de Concorrência China-UE, o Workshop ChinaEU sobre Questões Práticas para a Análise de Concentrações, o Projecto de Melhoramento do Direito Económico e Direito das Empresas China-Japão, e os Seminários Antimonopólio com a Associação Americana dos Bares e a USTDA. Ver China's Trade Policy Review, WT/TPR/S/230, p. 60-61.

106 HAMP-LYONS, Christopher, op. cit., p. 1578.

107 CHEN, Bing; GU, Minkang, (2010), "Evolution and Inspiration of Comity Doctrine of Extraterritorial Application of Sherman Act”. Law Science Magazine, n. 5, p. 102-118.

108 SINGH, Ajit, (2002), "Competition and Competition Policy in Emerging Markets: International and Developmental Dimensions”. Unctad G-24 Discussion Paper Series, Unctad/GDS/MDPB/G24/18.

109 EMCH, Adrian; HAO, Qian, (2007), op. cit.

110 HAMP-LYONS, op. cit., p. 1620-1.

111 HAMP-LYONS, Christopher, op. cit., p. 1611.

112 GAL, Michal, (2004), “The Ecology of Antitrust: Preconditions for Competition Law Enforcement in Developing Countries". In: Unctad, Competition, Competitiveness and Development, New York and Geneva, p. 20. Ver também MATEUS, Abel M., (2010), "Competition and Development: Towards an Institutional Foundation for Competition Enforcement”. World Competition, n. 33, p. 275-300.

Wei Dan

Faculty of Law - University of Macau Av. Padre Tomas Pereira, Taipa Macau Special Administrative Region - China danweilaumac.mo
PRofessora Associada E DIRETORA do InStituto PARA Estudos Jurídicos Avançados da Faculdade de Direito dA UnIVERSIDADE DE MACAU

Editora-Chefe de Macau Law Review Árbitra do Centro de Arbitragem de World Trade Center Macau

Doutora em Direito PELA Universidade de CoImbra 